\title{
Genotype by Environment Interaction and Stability of Pod Yield of Elite Breeding Lines of Groundnut (Arachis hypogaea L.) in Eastern Ethiopia
}

\author{
Amare Kebede ${ }^{\star}$ and Tamado Tana
}

School of Plant Sciences, Haramaya University, Post Box No: 157, Dire Dawa, Ethiopia

\begin{tabular}{|c|c|}
\hline \multirow[b]{2}{*}{ 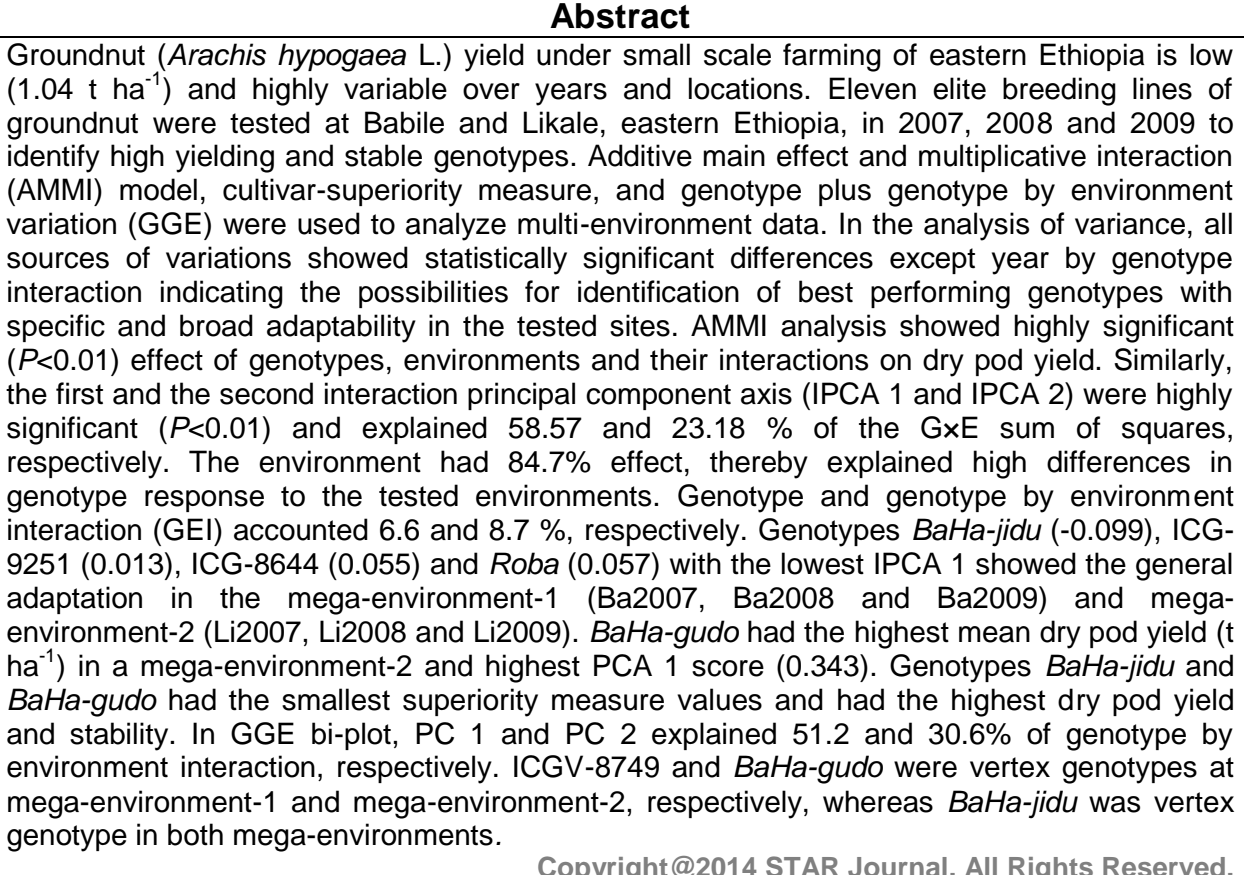 } & Article Information \\
\hline & $\begin{array}{l}\text { AMMI } \\
\text { GGE bi-plot } \\
\text { Groundnut } \\
\text { Mega-environment } \\
\text { Stability } \\
\text { Environment } \\
\text { Eastern Ethiopia }\end{array}$ \\
\hline
\end{tabular}

\section{INTRODUCTION}

Groundnut (Arachis hypogaea L.) is an annual legume, best adapted to warm climatic conditions and is dominantly grown under rain-fed conditions in potential areas of Ethiopia. The estimated total area coverage of groundnut in Ethiopia was about 49,603 hectares with an estimated annual production of 71606.80 tons with an average dry pod yield of $1.44 \mathrm{t} \mathrm{ha}^{-1}$ in 2010/11 cropping season. East Hararghe zone accounted for $43.4 \%$ (21527.12 ha) of the national area of production and currently groundnut is replacing other major crops in East Hararghe zone of eastern Ethiopia due to its high nutritional and market value, adaptation to marginal soil types, drought tolerance and resistance to striga infestation. However, its dry pod yield is very low (1.04 tons $\mathrm{ha}^{-1}$ ) in eastern Ethiopia as compared to the national average yield (1.44 tons ha ${ }^{-1}$ ) (CSA, 2011). Moreover, this yield is far less than the potential (2.02 tons ha ${ }^{-1}$ ) and highly variable over years and locations, mainly due to the various biotic and abiotic production constraints.
Among the factors contributing to the low yield level is due lack of high yielding and stable varieties. Temporal and spatial instability of quantitative traits of crops have connection with the unreliability of crop yields and thereby food insecurity at household and national level. In most cases, genotypes grown in different environments did yield differently due to genotype by environment interaction (GEI). Therefore, multi-environment trials (MET) are required to identify specific and the general adaptability of genotypes.

The additive main effect and multiplicative interaction (AMMI) model involves the Additive Main effects of ANOVA along with the Multiplicative Interaction effects of principal components analysis (PCA). This model is used frequently for the analysis of multi-environmental data in plant breeding programs and more accurate in predicting future cultivar performance than cell means (Crossa et al., 1990; Ebdon and Gauch, 2002). 


\section{Amare Kebede and Tamado Tana}

Cultivar-superiority measure is one of the analysis used in multi-environment trials for the selection of high yielding, stable and reliable genotypes. In cultivarsuperiority measure, genotypes with the smallest values incline to be stable and better in yields (Lin and Binns, 1988).

Genotype plus genotype by environment variables (GGE) bi-plot allows for assessing the performance of genotypes in the tested environments. Phenotypic variation of genotypes across environments results from environmental and genotypic variations and genotype by environment interaction. Environmental variation is the dominant source of phenotypic variation. For single-trait data, vertex cultivars are considered to be the highestyielding genotypes in the environments that occur in the same sector (Yan and Kang, 2003). The objective of this
Sci. Technol. Arts Res. J., April-June 2014, 3(2): 43-46

study was to identify high yielding, adapted and stable groundnut genotypes across different environments in eastern Ethiopia.

\section{MATERIALS AND METHODS}

The local check (Oldhale) and ten elite breeding lines of groundnut, which have been imported from the International Crops Research Institute for Semi Arid Tropics (ICRISAT), were evaluated in a multi-environment under rain fed conditions at Haramaya University research sites, namely Babile and Likale in 2007, 2008 and 2009 main cropping seasons. Thus, combinations of the locations (Babile and Likale) and years (2007, 2008 and 2009) were treated as six environments (Ba2007, Ba2008, Ba2009, Li2007, Li2008 and Li2009). For ease of assessment, genotypes were coded as

\begin{tabular}{llllll}
\hline Genotype & Pedigree & Code & Genotype & Pedigree & Code \\
\hline BaHa-jidu & NC-AC-2748xChico & G1 & ICG-9251 & ICG-9251 & G7 \\
GRRP-16 & GRRP-16 & G2 & ICG-8644 & ICG-8644 & G8 \\
BaHa-gudo & ICGV-88357 & G3 & Werer-962 & ICGS20 XI.NO95-A & G9 \\
ICGV-8749 & ICGV-8749 & G4 & Roba & ICG-7794 & G10 \\
NC-5 & NC-5 & G5 & Oldhale & Local cultivar & G11 \\
ICGS-62 & ICGS-62 & G6 & & & \\
\hline
\end{tabular}

Site Description

\begin{tabular}{clccc}
\hline Location & \multicolumn{2}{l}{ Geographical coordinates } & Altitude (m.a.s.I) & Soil textural class \\
\hline Babile & $09^{\circ} 13^{\prime} 09^{\prime \prime} \mathrm{N}$ & $042^{\circ} 19^{\prime} 25^{\prime \prime} \mathrm{E}$ & 1642 & Sandy loam \\
Likale & $09^{\circ} 10^{\prime} 53^{\prime \prime} \mathrm{N}$ & $042^{\circ} 21^{\prime} 58^{\prime \prime} \mathrm{E}$ & 1612 & Sandy loam \\
\hline
\end{tabular}

The experiment was arranged in randomized complete block design with three replications. The spacing between rows and between plants was $0.60 \mathrm{~m}$ and $0.10 \mathrm{~m}$, respectively. The number of rows per plot was 5 and the dry pod yield was collected from middle three rows.

Multivariate method, Additive Main Effects and Multiplicative Interaction (AMMI) model was used to assess genotype by environment interaction (GEI) pattern. AMMI model is expressed as:

$$
Y_{i j l}=\mu+G_{i}+E_{j}+\left(\sum \lambda_{k} \alpha_{i k} \gamma_{j k}\right)+d_{i j}+e_{i j l}
$$

Where $\lambda_{k}$ is $k^{\text {th }}$ eigenvalue, $\alpha_{i k}$ is the principal component score for the $i^{\text {th }}$ genotype for the $k^{\text {th }}$ principal component axis, $\gamma_{\mathrm{jk}}$ is principal component score for the $j^{\text {th }}$ environment for the $k^{\text {th }}$ principal component axis, $d_{i j}$ is residual $\mathrm{G} \times \mathrm{E}$, not explained by model.

In addition, a cultivar-superiority measure was used to compute stability coefficients for genotype by environment data of each genotype. It is computed as the sum of the squares of the differences between its mean in each environment and the mean of the best genotype there, divided by twice the number of environments (Lin and Binns, 1988).

Genotype plus genotype by environment variation (GGE) was used to assess the performance of genotypes in different environments. The environmental effects were removed from the data and results obtained from the data were used to calculate environment and genotype scores and these scores were used to plot the standard principal component bi-plots (Yan and Kang, 2003).

\section{Statistical Analysis}

Analysis of variance was carried out with a statistical analysis system (SAS) version 9.0 software (SAS Institute Inc., 2002). Additive Main Effect and Multiplicative Interaction (AMMI) analysis, cultivar-superiority measure, and GGE bi-plots were performed using GenStat $15^{\text {th }}$ edition statistical package (VSN International, 2012).

\section{RESULTS AND DISCUSSION}

Analysis of variance was carried out to determine the effect of genotype, location, year and their interaction on dry pod yield of groundnut genotypes (Table 1). Accordingly, except year by genotype interaction, all sources of variances showed statistically significant differences.

Table 1: Mean squares from combined analysis of variance for dry pod yield over two locations and three years.

\begin{tabular}{|c|c|c|}
\hline Source of Variance & Df & Mean Square \\
\hline Location & 1 & $21.39^{* *}$ \\
\hline Year & 2 & $9.93^{* *}$ \\
\hline Year×Location & 2 & $22.94^{\star \star}$ \\
\hline Rep (Year×Location) & 18 & $0.58^{* *}$ \\
\hline Genotype & 10 & $0.68^{* \star}$ \\
\hline Location×Genotype & 10 & $0.39^{* *}$ \\
\hline Year×Genotype & 20 & $0.07 \mathrm{~ns}$ \\
\hline Year×Location $\times$ Genotype & 20 & $0.18^{* *}$ \\
\hline Error & 180 & 0.086 \\
\hline CV (\%) & & 16.6 \\
\hline
\end{tabular}




\section{Amare Kebede and Tamado Tana}

Genotype by location interaction showed a highly significant difference indicating the need for independent breeding program to identify best performing genotypes for each tested sites. In the combined analysis, interactions among year, location and genotype were highly significant which indicates response variation among genotypes in the tested environments.

AMMI analysis of dry pod yield of eleven genotypes in six environments showed that genotypes, environments and their interactions were highly significant $(P<0.01)$. IPCA 1 and IPCA 2 were also statistically significant $(P<0.01)$ and explaining 58.57 and $23.18 \%$ of the GxE sum of squares, respectively (Table 2 ).

Table 2: AMMI analysis for eleven groundnut genotypes studied in six environments

\begin{tabular}{llll}
\hline Sources of variation & Df & SS & MS \\
\hline Blocks within environment & 18 & 10.45 & $0.581^{\star *}$ \\
Treatments & 65 & 102.84 & $1.582^{\star *}$ \\
Genotypes & 10 & 6.80 & $0.680^{\star *}$ \\
Environments & 5 & 87.11 & $17.422^{\star *}$ \\
G $\times$ E & 50 & 8.93 & $0.179^{\star *}$ \\
IPCA 1 & 14 & 5.23 & $0.374^{\star *}$ \\
IPCA 2 & 12 & 2.07 & $0.173^{\star}$ \\
Residual & 24 & 1.62 & 0.068 \\
Error & 180 & 15.51 & 0.086 \\
\hline
\end{tabular}

${ }^{* *}$ and ${ }^{*}$ significant level at $P<0.01$ and $P<0.05$, respectively $\mathrm{df}=$ degree of freedom, $\mathrm{SS}=$ sum of squares, $\mathrm{MS}=$ mean squares

The environment had the highest effect $(84.7 \%)$ of the treatment sum of squares indicating the environments were diverse and caused most of the variation in dry pod yield. Such highest variability due to the environment were also reported on groundnut and other crops (Crossa et al. 1990; Casanoves, 2005; Aina et al., 2007). On the other hand, genotypes and $\mathrm{G} \times \mathrm{E}$ accounted only $6.6 \%$ and $8.7 \%$ of the treatment sum of squares, respectively.

Genotypes BaHa-jidu (-0.099), ICG-9251 (0.013), ICG8644 (0.055) and Roba (0.057) had IPCA 1 values close to zero showing that these genotypes had general adaptation in the tested environments. However, based on best dry pod yield performance, BaHa-jidu (2.02 $\left.\mathrm{t} \mathrm{ha}^{-1}\right)$ was recommended for production. BaHa-gudo (0.579) had a highest IPCA 1 score, which indicates its highest interaction with the specific environment, best in mean dry pod yield, and consequently recommended for production (Table 3). Similarly, high yielding groundnut genotypes were obtained in a unique mega-environment (Casanoves et al., 2005). Mitrovic et al. (2012) also followed the same procedure to select specific and broad adaptable maize hybrids.

Among studied varieties, BaHa-jidu (0.026) and BaHa-gudo (0.044) had smallest superiority measure values, which showed their best yield performance and dry pod yield stability (Table 3).

In the AMMI selection of genotypes, BaHa-jidu took the third position in Li2007 and the second best position in all other environments. Accordingly, BaHa-jidu showed dynamic stability, but its relative performance was consistent and predictable across environments, which is desirable characteristics for crop production at various
Sci. Technol. Arts Res. J., April-June 2014, 3(2): 43-46

levels of agricultural inputs. This narrow change of the differential response of BaHa-jidu in different environments is an indication of its wide adaptability. BaHa-gudo took the first position in the megaenvironment-2 indicating consistent and predictable dry pod yield performance in the specific environment (Table 4 ). The report indicated that the interaction pattern of some locations across crop species are consistent so that they are highly predictable in year to year interaction with genotypes (Ebdon and Gauch, 2002). In this line, the Babile and Likale research sites were found good selection sites for broad and specific based adapted groundnut genotypes. Similarly, Aina et al. (2007) identified sites suitable for crop improvement program based on genotype performance.

Table 3: Mean dry pod yield, IPCA scores and stability coefficients for eleven genotypes tested in six environments

\begin{tabular}{lcccc}
\hline Genotype & $\begin{array}{c}\text { DPY } \\
\text { (t ha }^{-1} \text { ) }\end{array}$ & IPCA 1 & IPCA 2 & $\begin{array}{c}\text { Genotype } \\
\text { superiority } \\
\text { measure }\end{array}$ \\
\hline BaHa-jidu & 2.02 & -0.099 & 0.009 & 0.026 \\
GRRP-16 & 1.82 & -0.366 & 0.320 & 0.109 \\
BaHa-gudo & 1.97 & 0.579 & 0.343 & 0.044 \\
ICGV-8749 & 1.81 & -0.559 & -0.117 & 0.126 \\
NC-5 & 1.76 & -0.200 & 0.088 & 0.107 \\
ICGS-62 & 1.78 & -0.204 & -0.196 & 0.108 \\
ICG-9251 & 1.85 & 0.013 & -0.420 & 0.066 \\
ICG-8644 & 1.51 & 0.055 & 0.259 & 0.254 \\
Werer-962 & 1.69 & 0.341 & -0.202 & 0.121 \\
Roba & 1.74 & 0.057 & 0.235 & 0.110 \\
Oldhale & 1.46 & 0.384 & -0.317 & 0.275 \\
\hline
\end{tabular}

IPCA 1 = first interaction principal component axis, IPCA 2 = second interaction principal component axis, DPY= dry pod yield.

Table 4: First four AMMI selections of genotypes per environment

\begin{tabular}{|c|c|c|c|c|c|}
\hline \multirow{2}{*}{ Environment } & \multirow{2}{*}{$\begin{array}{c}\text { Mean } \\
\text { DPY }\left(\mathrm{t} \mathrm{ha}^{-1}\right)\end{array}$} & \multicolumn{4}{|c|}{ Genotype rank } \\
\hline & & 1 & 2 & 3 & 4 \\
\hline Ba2007 & 1.774 & G2 & G1 & G4 & G5 \\
\hline Ba2008 & 2.175 & G7 & G1 & G4 & G6 \\
\hline Ba2009 & 2.197 & G4 & G1 & G7 & G6 \\
\hline Li2007 & 2.167 & G3 & G9 & G1 & G7 \\
\hline Li2008 & 1.715 & G3 & G1 & G2 & G10 \\
\hline Li2009 & 0.556 & G3 & G1 & G7 & G2 \\
\hline
\end{tabular}

In GGE bi-plot (Figure 1), PC 1 and PC 2 explained 51.2 and $30.6 \%$, respectively, of genotype by environment interaction and made a total of $81.8 \%$. The other study conducted on the same crop showed 79 to $85 \%$ total of PC 1 and PC 2 (Casanoves, 2005). Environments $\mathrm{Ba} 2007, \mathrm{Ba} 2008$ and Ba2009 were ellipse rounded identifying the homogeneity of the environments (megaenvironment-1). Similarly, environments Li2007, Li2008 and Li2009, were ellipse rounded, showed the similarity of the environments (mega-environment-2).

In dry pod yield data, BaHa-jidu was the vertex variety of both mega-environments. BaHa-gudo was vertex variety yield in the mega-environment- 2 . These reveal that $\mathrm{BaHa}$-jidu and BaHa-gudo were the best varieties in dry pod yield in their respective environments (Figure 1). 


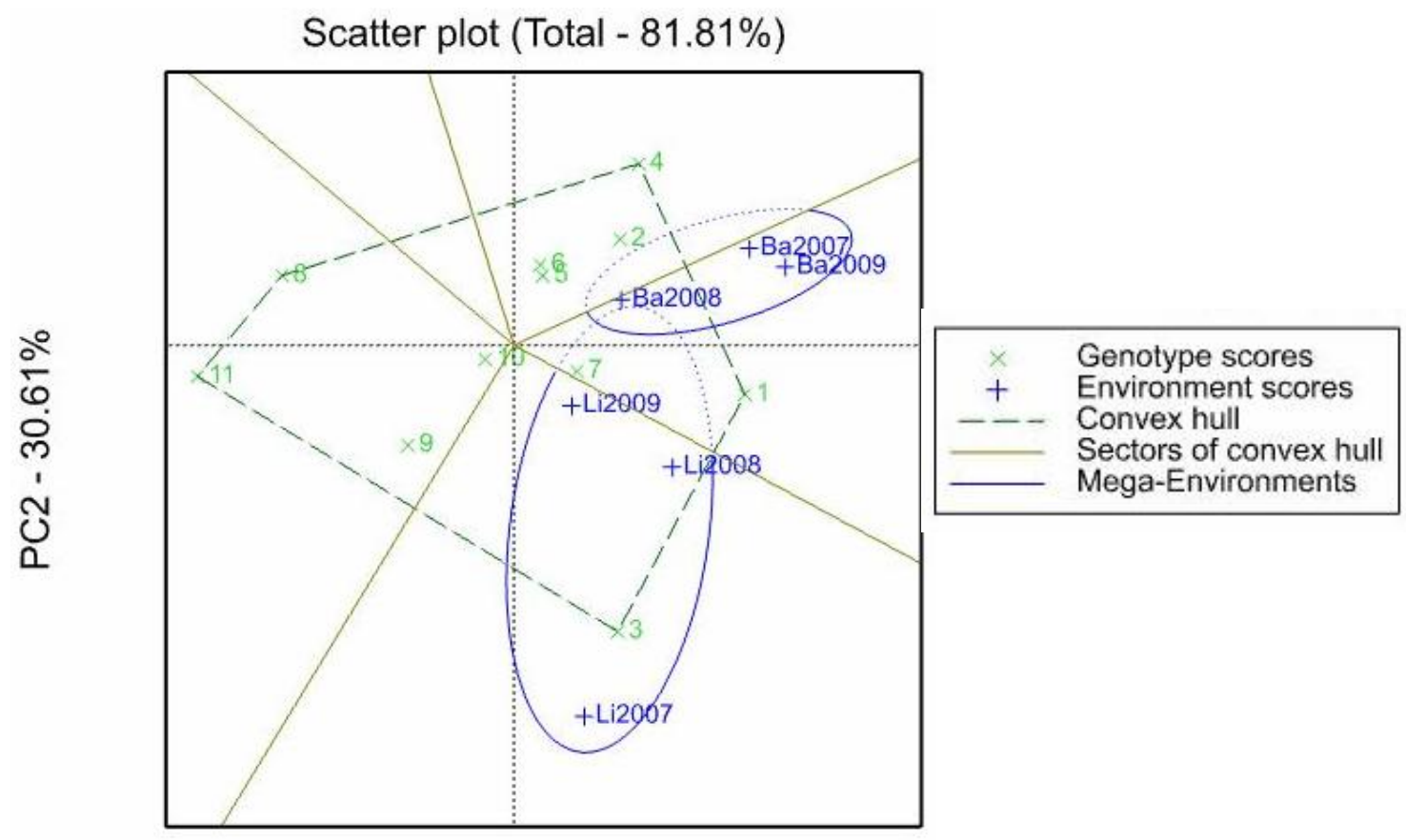

PC1 - $51.20 \%$

Figure 1: Genotype plus genotype by environment variation (GGE) bi-plot showing the performance of genotypes in different environments. G1, G2, G3, G4, G5, G6, G7, G8, G9, G10 and G11 are designated as 1, 2, 3, 4, 5, 6, 7, $8,9,10$ and 11, respectively. Dashed ellipse lines indicated the extension of ellipse in another sector.

\section{CONCLUSIONS}

The tested environments were diverse and had the greatest effect on dry pod yield variation among groundnut genotypes. Babile and Likale research sites to be suitable for the identification of best performing groundnut genotypes with broad and specific adaptability. Moreover, trials for extended years at the tested sites would not be required to select best performing genotypes. BaHa-jidu, ICG-9251, ICG-8644 and Roba had general adaptation in the mega-environment-1 (Ba2007, Ba2008 and Ba2009) and mega-environment-2 (Li2007, Li2008 and Li2009). Among which, BaHa-jidu showed highest dry pod yield performance and recommended for production. BaHa-gudo showed highest interaction with the specific mega-environment and highest dry pod yield. Consequently, recommended for production. In general, BaHa-jidu showed wide adaptability, highest, consistent and predictable dry pod yield across environments. Similarly, BaHa-gudo showed highest, consistent and predictable dry pod yield in the mega-environment-2.

\section{ACKNOWLEDGEMENTS}

The authors are very grateful to the Ethiopian Institute of Agricultural Research for financial support.

\section{REFERENCES}

Aina, O.O., Dixon, A.G.O., and Akinrinde, E.A. (2007). Additive main effect and multiplicative interaction (AMMI) analysis for yield of cassava in Nigeria. Journal of Biological Sciences 7(5): 796-800.

Casanoves, F., Baldessari, J., and Balzarini, M. (2005). Evaluation of Multi Environment Trials of Peanut Cultivars. Crop Science 45:18-26.
Crossa, J., Gauch, H.G. Jr. and Zobel, R.W. (1990). Additive main effect and multiplicative interactions analysis of two international maize cultivar trials. Crop Science 30:493500.

CSA (Central Statistical Agency). (2011). Area, Production and Yield of Crops for Private Peasant Holdings for Meher Season 2010/2011. Addis Ababa, Ethiopia.

Ebdon, J.S., and Gauch, H.G., Jr. 2002. Additive main effect and multiplicative interactions analysis of national turf grass performance trials: II. Cultivar recommendations. Crop Science 42:497-506.

Ebdon, J.S., and Gauch, H.G. Jr. (2002). Additive main effect and multiplicative interactions analysis of national turf grass performance trials: I. Interpretation of Genotype x Environment Interaction. Crop Science 42:489-496.

Lin, C.S., and Binns, M.R. (1988). A superiority performance measure of cultivar performance of cultivar $x$ location data. Canadian Journal of Plant Science 68:193-198.

Mitrovic B., Stanisavljevi, D., Treski, S., Stojakovic, M., Ivanovic, M., Bekavac, G., and Rajkovic, M. (2012). Evaluation of experimental maize hybrids tested in multilocation trials using AMMI and GGE biplot analysis. Turkish Journal of Field Crops 17 (1): 35-40.

SAS Institute Inc. (2002). User Guide for the SAS System, Version 9 for Microsoft Windows, Cary, NC: SAS Institute Inc.

VSN International ( 2012). GenStat for Windows 15th Edition. VSN International, Hemel Hempstead, UK. Web page: GenStat.co.uk.

Yan, W., and Kang, M.S. (2003). GGE Biplot Analysis: a Graphical Tool for Breeders, Geneticists and Agronomists. CRC Press, Boca Raton. 